\title{
DEVELOPING AN ECOLOGICAL AND MIGRATION SYSTEM FOR ICHTHYOFAUNA ON THE CRIŞUL REPEDE RIVER NEAR THE CITY HALL OF ORADEA
}

\author{
Eric L., KAY ${ }^{1}$ and Răzvan, VOICU² \\ ${ }^{1}$ Kay Associates, Comox, BC., Canada, erickay@kayassociates.com \\ ${ }^{2}$ I.N.H.G.A., Bucharest, România, rzvnvoicu@yahoo.com, getiiliberi@gmail.com
}

\begin{abstract}
Crişul Repede River, near the Ferdinand Bridge from the Oradea Town.

The proposed solution provides building of a system to facilitate fish migration, placed on the left bank of Crişul Repede, meant to restore the longitudinal connectivity of Crişul Repede River in front of the Ferdinand Bridge weir and to facilitate the access of the migratory fish species to upstream breeding habitats.

The proposed migration system are based on the gravitational fall of water and will lead to the restoration of the longitudinal connection of the Crişul Repede River near the weir selected as case study, and will reconnect a habitat with a length of approximately $4 \mathrm{~km}$, that will contribute to insuring of optimal conditions for developing migratory fish species present in the area KEYWORDS: ecobiome's functionality, ecosystem, Crisul Repede River, connectivity, dynamics of the watercourse
\end{abstract}

\section{INTRODUCTION}

\section{Biological engineering}

Channeled stream and river systems, with cement and steel sides does not allow for vegetative attachment.

Vegetation provides an environment to support flora and fauna, which in turn provides enhancement of life to aquatic watersourses.

It is suggested that a further study be performed to establish the practicality and methods to accomplish the effective placement of enhanced surfaces that would support growth, without impeding critical water flows.

The subject of this article represents an European theme of great topicality and interest regarding the restoration of the water courses affected by the hydromorphological pressures created by the presence of transversal works which lead to the interruption of longitudinal connectivity of rivers, stopping the fish migration and modifying the flow regime. River Crisul Repede is channelled a covered by concrete and has not meandered in the village of Oradea, a fact which has a negative impacts on the dynamics of the watercourse.

There are many hydrotechnical facilities along the Crisul Repede River, including spillway sills. In the city of Oradea there are some sills with the following locations: CFR Bridge, the City Hall of Oradea, Dacia Bridge etc. These spillway sills seriously affect the connectivity of the Crisul Repede River, strongly reducing its biodiversity and ecological valence, implicitly. The need for longitudinal connectivity of watercourses represents an essential condition for the Water
Framework Directive approved by the European community and, therefore, it should be applied to all streams containing migratory species. The subject of this case study proposes an ecotechnical solution consisting of the frontal connectivity in the city of Oradea. The solution proposed for fish fauna migration upstream - downstream of the spillway sill situated at the City Hall of Oradea is practical it can be developed without any expensive technology and does not affect the spillway sill structure and associated construction.

\section{THE SOLUTION PROPOSED FOR FISH FAUNA MIGRATION}

This paper represent a part of a complex study regarding the restoration of longitudinal connectivity of Crişul Repede River accomplished in a framework of a more large Programme of Measures for restoring longitudinal and lateral connectivity of Crişul Repede River. The subject of article represents an European theme of great topicality and interest regarding the restoration of the water courses affected by the hydromorphological pressures created by the presence of transversal works which lead to the interruption of longitudinal connectivity of rivers, stopping the fish migration and modifying the flow regime.

The spillway sill is located near Ferdinand Bridge (in the center) on the Crişul Repede River, near Oradea City Hall (figure 1), also known as Central Bridge or City Hall Bridge, has been selected for the present case study. The Crişul Repede River bed width is $50 \mathrm{~m}$ at the spillway sill, it has $25.6 \mathrm{~m}^{3} / \mathrm{s}$ flow rate and its water speed is $0,461 \mathrm{~m} / \mathrm{s}$ [Source: ABA Crişuri]. 


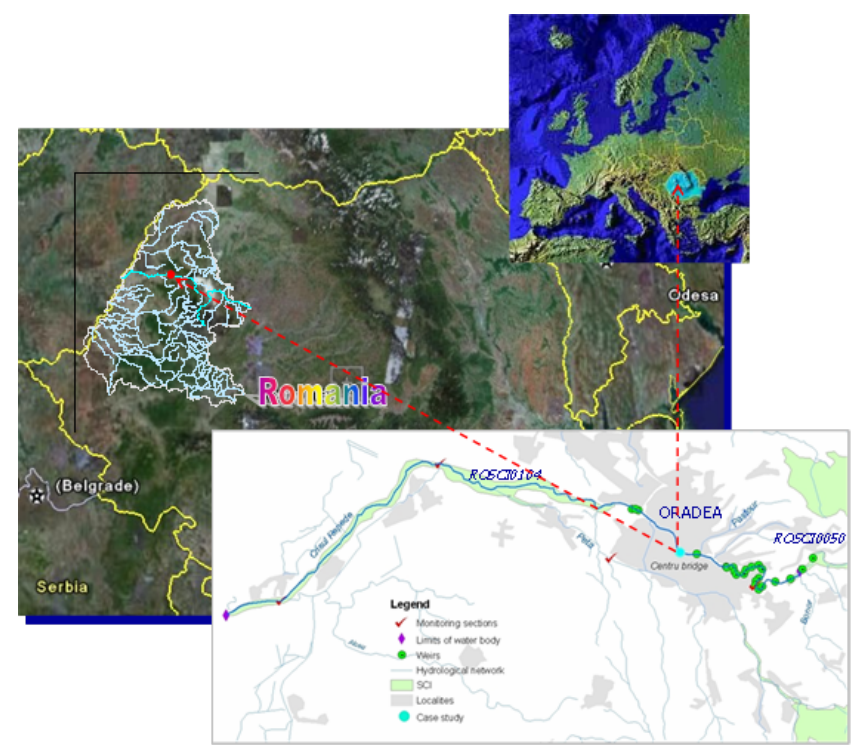

Figure 1. Locating the spillway sill Central Bridge

The analysed spillway is $1.5 \mathrm{~m}$ high, $1 \mathrm{~m}$ thick and 1 $\mathrm{m}$ drop, $50 \mathrm{~m}$ length consisting of a toe basin and the revetment located below water level (figure 2)

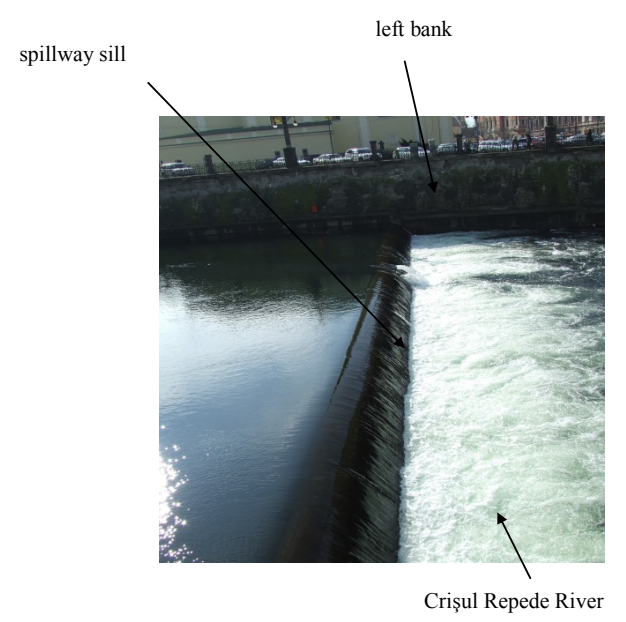

Figure 2. Spillway sill near the City Hall of Oradea

The spillway sill near the City Hall of Oradea stops migration of ichthyofauna in the Crişul Repede River, but it also maintains wood, plastic bottles etc. (figure 3 and figure 4).

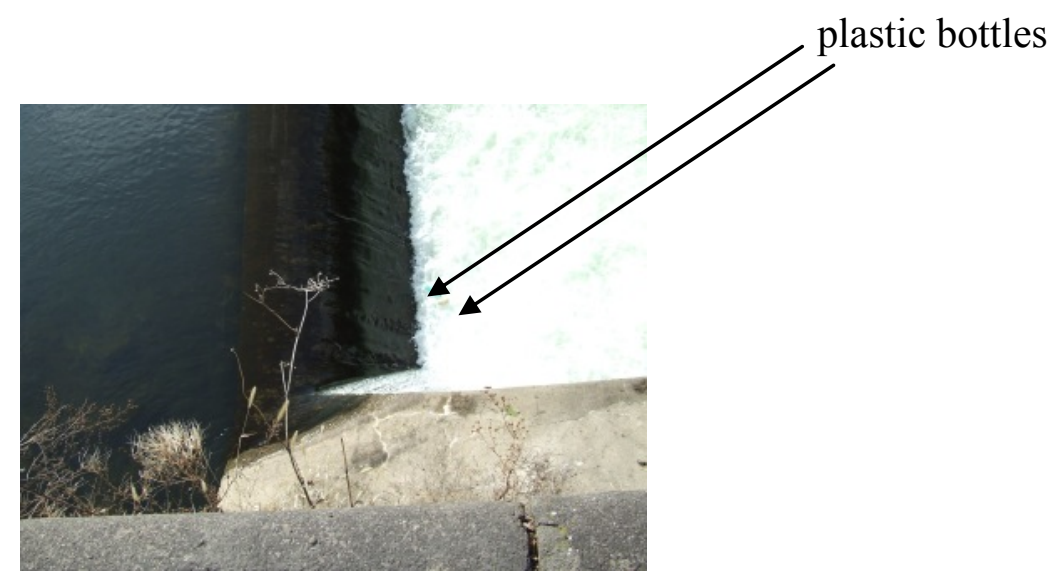

Figure 3. 


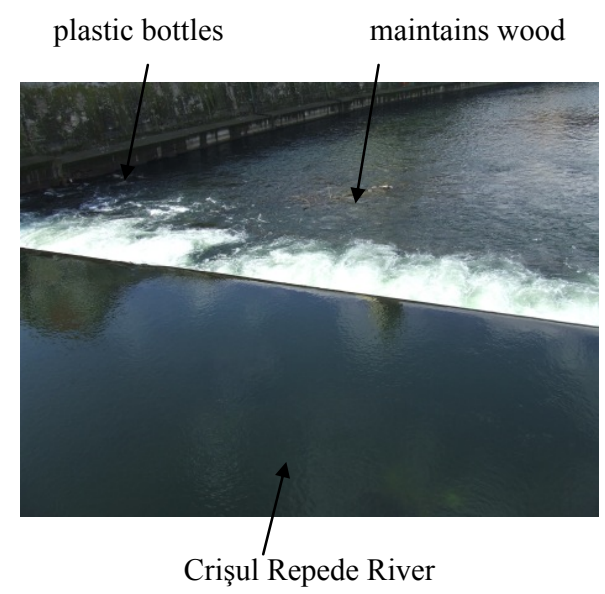

Figure 4.

To develop an ecological and migrating system for ichthyofauna at the same time, we should redirect the Crişul Repede water flow using some metal sheet

piles, which will redirect all water flow rate towards two channels (figure 5).

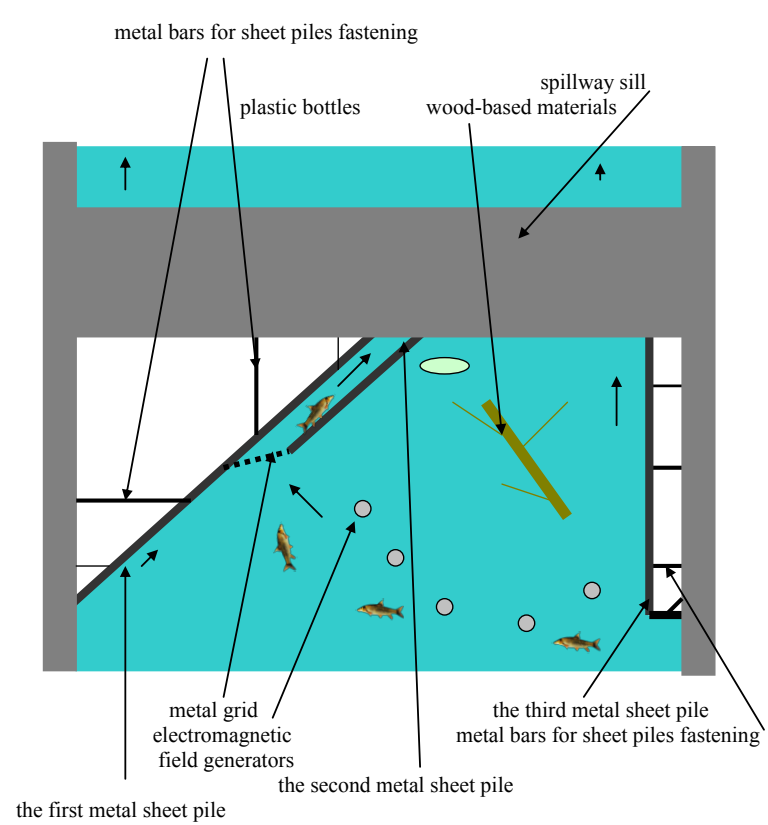

Figure 5. The position of three metal sheet piles - indicative scheme

The metal sheet piles will increase the water level in the two canals. The first sheet pile will be fixed both to the concrete left river bank and the spillway sill by the means of the several metal bars. The sheet pile in the middle has the smallest dimensions and will be fixed by the spillway sill, by the river bed and also by the first sheet pile. (figure.6) The third sheet pile will be fixed to the right bank by the means of several metal bars.

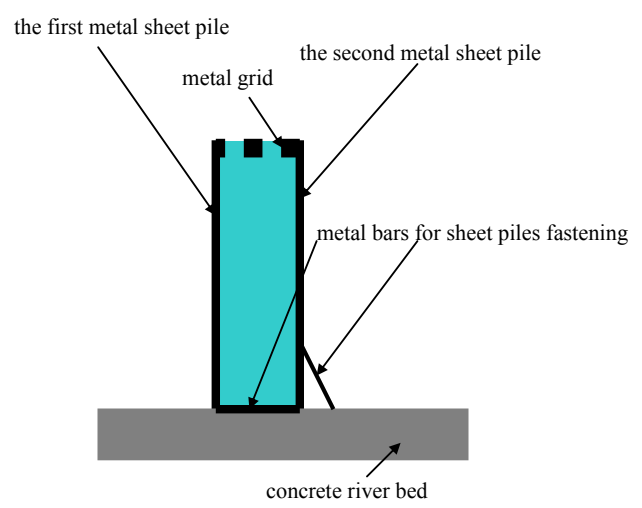

Figure 6. Fixing the sheet pile in the middle of the system-indicative scheme 
The canal formed by the first and the second sheet piles is used for fish fauna migrating, and the second canal formed by the second and the third sheet piles is used to collect the plastic bottles and wood-based materials. At its upstream end the first canal is fixed to a metal grid to redirect, the awash floating elements towards the second canal (figure 5). On the canal formed by the first and the second sheet piles is used for fish fauna migrating, and the second canal formed by the second and the third sheet piles exist electromagnetic field generators wich redirectioning the ichthyofauna to the first channel(figure 5).

Being positioned at a level even with the surface of the water, the metal grid does not stop the ichthyofauna exit and enter the canal. The two sheet piles of the first canal will be welded by another canal passing over the spillway sill and taking all the water in the canal formed by the two sheet piles (figure 7).

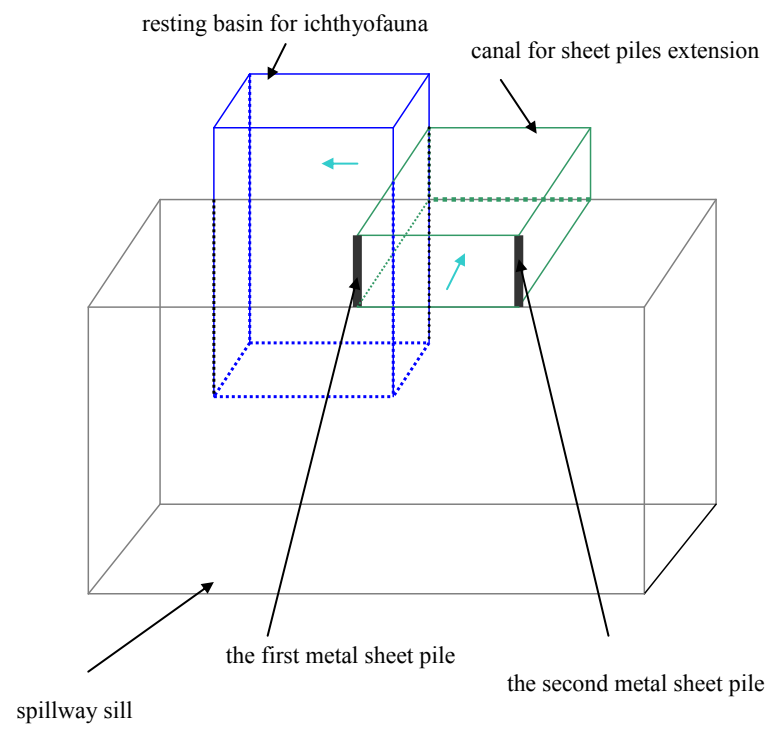

Figure 7. Positioning the resting basin for ichthyofauna - indicative scheme

In the upper part of the resting basin for fish fauna there is a crenel to which a canal made of galvanized steel sheet will be fixed. This rectangular canal is fixed to the spillway sill by the means of some metal dowels and bars (figure 8). The canal made of galvanized steel sheets is not closed because all the water is redirected by the sheet piles, which give the ichthyofauna the adequate visibility.

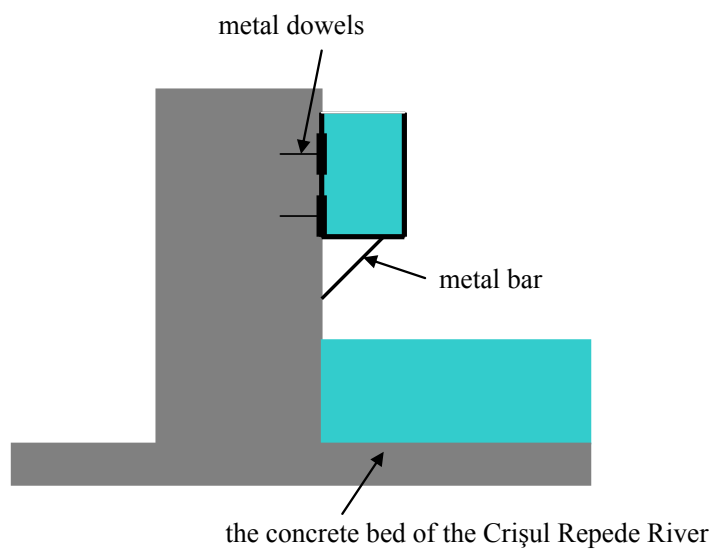

Figure 8. Positioning the canal made of galvanized steel sheets-indicative scheme

The rectangular canal is built into the slope and it will also be fixed on the left bank by the means of some metal dowels and bars (figure 9). Water velocity in the canal will be the same as for the Crişul Repede water river in the study area. The two resting basins for the ichthyofauna help the fish population to migrate effortlessly above the spillway sill. From the left bank, this canal will get in the watercourse. 


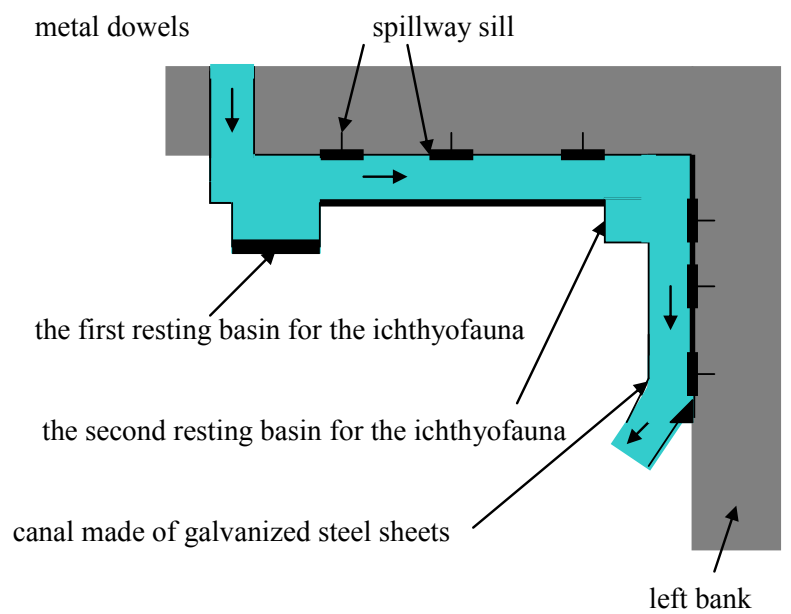

Figure 9. Fixing the canal made of galvanized steel sheets to the left bank- indicative scheme

A canal made of galvanized steel sheets will be welded to the canal formed by the second and the third sheet piles and it will undertake the entire water flow of the channel formed by the two sheet piles. A metal angle frame is fastened to four metal pillars downstream of the spillway sill (figure. 10). A metal angle frame is built from the angle metal with four meters length and three meters width. On the horizontal plane the thickness of metal angle is five centimeters, eight centimeters width and ten centimeters height(figure 11). Each pillar is soldered on the contact part with the metal angle frame two sheet piles for the metal angle frame stabilization.(figure 12). The material used for the built fixing system for the mobile basin is stainless and has a strong structure.

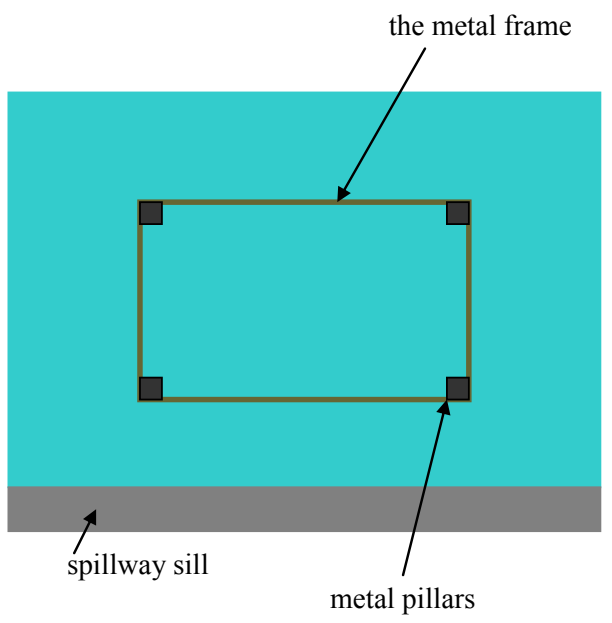

Figure 10. Positioning the metal frame on the watercourse- indicative scheme

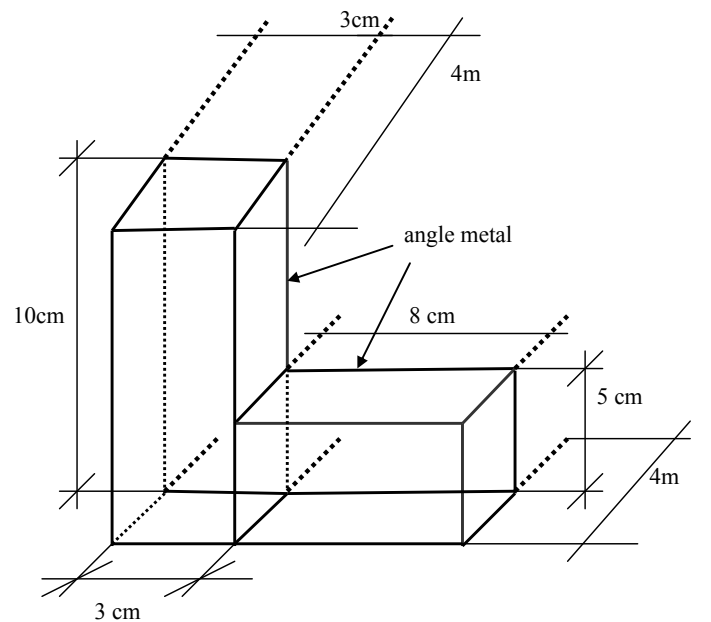

Figure 11. The dimensions of the angle metal-indicative scheme 


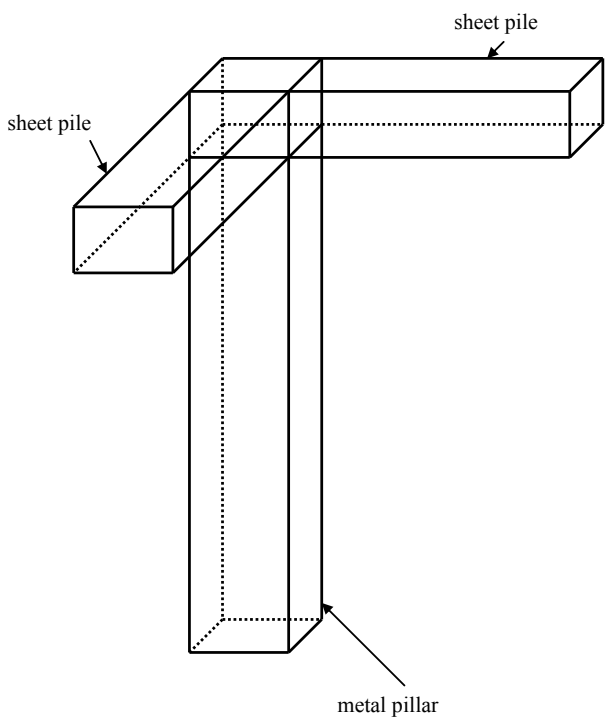

Figure 12. Positioning the metal pillar- indicative scheme

A mobile basin made of metal grille shall be fixed on the metal frame. The mobile basin is provided with four metal rings welded laterally where four chains or cables shall be fixed; therefore, they are used to lift the basin by the means of an auto-crane or a fixed crane (figure 13). All plastic bottles and wood-based materials arrive into the mobile basin after being redirected through a canal.

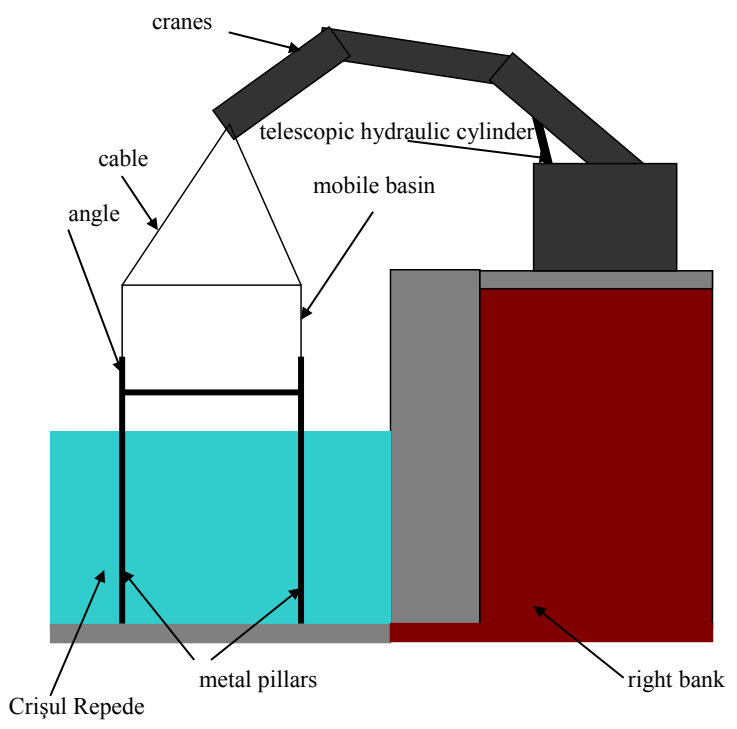

Figure 13. Positioning the crane on the right bank - indicative scheme

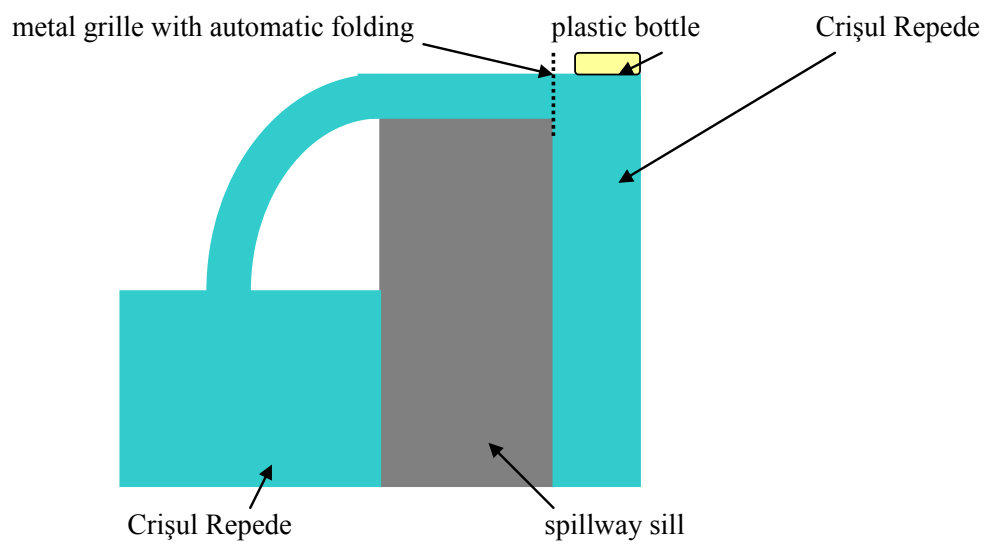

Figure 14. Positioning of the metal grille with automatic folding 
The mobile basin is lifted by the means of a crane fixed on a car or to the ground. The crane is provided with a cabin for one person, who will fix the four cables to the basin. When the mobile basin gets over a car transporting waste, the basin base consisting of two mobile doors opens automatically and thus all the waste can be thrown away. During these operations that do not last more than 30 minutes, a metal grille (with automatic folding) fixed to the spillway sill will stop waste from proceeding downstream of the spillway (figure 14).

\section{CONCLUSION}

This system of fish migration upstream - downstream of the spillway sill provides longitudinal connectivity of the Crisul Repede River representing an important issue in the local lotic ecosystem restoration. The solution proposed in this paper is practical it can be developed without any expensive technology and does not affect the spillway sill structure and associated construction. The proposed fish migration system will give some ecological (ensuring of fish migration and facilitate access to new aquatic habitats; increasing of biodiversity); economical (improving of local ecosystems functionality and ecological status of Crişul Repede River $\rightarrow$ Bonor - border (RW3.1.44_B7) water body) and social (improving recreational and angling opportunities) benefits for the study area.

\section{REFERENCES}

1. Bănărescu M. P. Fauna of P.R. R.. Academy Edition, Bucharest, 1964. (in Romanian).

2. Bănărescu M. P. and Bănăduc D., Habitats Directive (92/43/EEC) fish species (Osteichthyes) on the Romanian Territory, Acta Ichtiologica Romanica II - 2007, pp. 43-78.

3. Diaconu S., Cursuri de apa. Amenajare, impact, Reabilitare, Editura * $\mathrm{H}^{*} \mathrm{G} * \mathrm{~A}$, Bucuresti, 1999. 